\title{
Editorial
}

\section{ON THE WAY TO BODY DONATION}

\author{
Andreas Winkelmann \\ Institute of Anatomy, Medical School Brandenburg, Neuruppin, Germany \\ Federative International Committee on Ethics and Medical Humanities (Chair) of the \\ International Federation of Associations of Anatomists (IFAA)
}

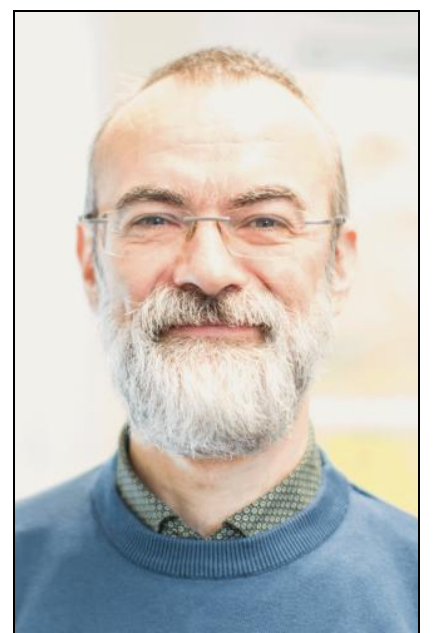

Getting "in touch" with the body of a deceased person is still the cornerstone of anatomical education in the vast majority of medical schools around the world - even if the use of anatomical dissection in the undergraduate medical curriculum has been on the decline in recent decades. There are some good reasons for this ongoing practice - to name just a few: the dissecting room is an activating learning environment, it gives access to an authentic human body that is more real than any representation (digital, plastic, or paper), and it can be used to engage students with existential questions of the body in life and death. Apart from basic anatomy education in medical school, bodies are also increasingly used in postgraduate education, for example in training courses for surgeons learning arthroscopy or hip replacement. There is therefore an ongoing necessity for anatomy departments to have access to human bodies.

Where should these bodies come from? The discipline of anatomy has a history of using executed criminals, starting with a short period in the $3^{\text {rd }}$ century BC in Alexandria and becoming common in late mediaeval Europe. With an increased need of bodies, some anatomists later turned to grave robbing. During the $19^{\text {th }}$ century, "unclaimed" bodies became the main source of bodies for anatomy departments - these were bodies of either those who died without relatives to claim the body or without the means to afford burial. Efficient body donation programs only started to develop during the 1960s and 1970s (their global history remains to be written).

In 2012, the International Federation of Associations of Anatomists released recommendations regarding the acquisition of bodies for anatomical purposes (IFAA, 2012). Based on ethical considerations, these recommendations clearly see body donation as the "gold standard" of body procurement - the informed consent of living persons to bequeath their mortal remains to scientific and educational use, based on an entirely voluntary decision in a non-commercial context. Recent reviews of the global situation regarding body donation, however, show that donation is still far from being the rule (Biasutto et al., 2014; Habicht et al., 2018). While donation is the exclusive source in large parts of Western Europe, North America and Oceania, the majority of anatomists worldwide still depend on unclaimed bodies, either partially or fully (Habicht et al., 2018). Moreover, recent investigations have revealed that for-profit companies in the United States trade donated body parts and ship them to many destinations around the globe 
(Champney, 2016; Shiffman and Levinson, 2018).

From what these references show, the situation in South America is patchy. In some places, body donation is the exclusive source, in others unclaimed bodies are the only source, and in some (including Argentina and Brazil), bodies come from both sources. Several South American countries are also listed as destination of commercial shipping from the United States, attesting to a need of cadavers that is not always satisfied by local sources. It is tempting but difficult to explain a lack of body donation with cultural or religious factors. As South America is a majority Catholic place, it is interesting to compare the situation to Europe, where, for example, Italy also struggles to convince people of donating their body. On the other hand, other majority Catholic countries like Spain or Ireland run well functioning donation programs. Therefore, other, more complex cultural factors seem to be involved.

It is important to explain why body donation should be the (exclusive) future of anatomical body acquisition. First of all, to base our anatomical practice on informed consent respects the individual autonomy of the deceased person involved. While the Helsinki Declaration asks for informed consent to make sure that no living person becomes the subject of medical research against their will, this should also apply to the mortal remains of a deceased person. Just as living people can determine by their last will what will happen to their property after death, they should also be able to determine what happens to their mortal remains.

Secondly, body donation respects the dignity of the dead body by accepting that the dignity of the living subject extends to their mortal remains. Even if the dead body is, in some respects, also a material object, body donation acknowledges that it is at the same time still connected to a person. It is therefore also central to the grief and the memories of relatives and friends, and to see the body as a donor respects the feelings of these relatives and friends.

There is no question that unclaimed bodies can also be treated in a respectful manner, but their use carries the risk of acting against the will of the deceased person (whose wishes usually remain unknown). Use of unclaimed bodies has also often discriminated against the poor and vulnerable members of a society, those who could not afford burial or could not protect their loved ones against acts of the authorities, even if they despised these acts (Jones and Whitaker, 2012). In many cases, this has led to mistrust of certain communities towards anatomists, a mistrust that can sometimes explain low donation rates - this is true, for example, for the Black African population in the United States, who are more reluctant to donate than other groups.

As a German anatomist, working in a country with well-functioning body donation programs, I am nevertheless not in a position to throw stones at those who still procure unclaimed bodies. In Germany, it took centuries of anatomical dissection before such donation programs were developed - they were installed in the 1960s and1970s in West Germany, and even later in the East. And sadly, despite functioning donation programs, Germany is also on the list of countries commercially importing body parts from the United States. However, I do think that, on a global scale, we live in a time of transition. As explained above, there are many good reasons to strive for body donation as the exclusive source of bodies, and I suggest that the use of unclaimed bodies should therefore be seen as a transient necessity.

Recent efforts by many anatomists around the world seem to support this view of living in a time of transition. They have surveyed students, other anatomists, or the local population in Greece (Halou et al., 2013), Turkey (Gürses et al., 2018), Iran (Abbasi Asl et al., 2016), India (Saha et al., 2015), or Brazil (Simao et al., 2016) to evaluate the willingness for body donation and possible barriers to this way of getting access to bodies. And while there are cultural and religious obstacles, it turns out that often lack of awareness of the option of body donation is an additional factor. Finally, even if I do not have evidence for this, it seems to me that anatomists and students are increasingly organising commemorative services and other rituals to honour the donors. Such activities create a link between anatomists and local communities, on whose trust medical schools depend if they want to work with bodies.

Gangata et al. (2010) suggest a five-step approach to foster body donation: (1) get support from other anatomy departments in your country, (2) get support from religious and community leaders, (3) seek legal advice, (4) look for a prominent person related to health care to publicly support a campaign, and (5) advertise to the public via diverse media channels. This approach may not work for everybody, but even in the presence of cultural or religious barriers to body donation, there is hope. Functioning body donation programs do exist on every continent and in very diverse cultural settings (Habicht et al., 2018); and there are promising examples of how donation programs were successfully installed, also by very diverse means.

In Thailand, for example, the Buddhist belief in rebirth conflicted with an anatomical interference 
with the dead body, but the embedding of dissection courses in Buddhist rituals and support by the royal family helped to pave the way for sufficient donation programs (Winkelmann and Güldner, 2004). In Indonesia, anatomists have started a new body donation program modelled on successful programs in Taiwan, which endorse donors by calling them "silent mentors" (Atmadja and Untoro, 2012). Finally, anatomists in Porto Alegre in Brazil were able to massively increase the number of donations within five years, mainly by a campaign to raise public awareness (da Rocha et al., 2013).

I conclude by recommending a recent paper by a British social anthropologist, available online (Hallam, 2017), which maybe an unusual read for anatomists, but offers a fascinating perspective on what anatomists (and students, donors, relatives) do. Hallam argues that in the body donation context, bodies are not just objectified and fragmented, but the practices she observed also produced "relationships, modes of connection and integration on social, material, and conceptual levels" and allowed to value bodies after death as material for learning, as gifts, and as persons. I hope that this describes the future of anatomy on a global scale.

\section{REFERENCES}

Abbasi Asl J, Nikzad H, Taherian A, Atlasi MA, Naderian H, Mousavi G, Kashani MM, Omidi A. 2016. Cultural acceptability and personal willingness of Iranian students toward cadaveric donation. Anat Sci Educ 10: 120-26.

Atmadja DS, Untoro E. 2012. The usage of the voluntary cadaver in education of medicine through silent mentor program. Indonesian Journal of Legal and Forensic Sciences 2: 3436.

Biasutto SN, Sharma N, Weiglein AH, Benia FM, McBride J, Bueno-López JL, Kramer B, Blyth $P$, Barros MD, Ashiru O, Ballesteros LE, Moxham BJ, Krishnan S. 2014. Human bodies to teach anatomy: Importance and procurement experience with cadaver donation. Revista Argentina de Anatomía Clínica 6: 72-86.

Champney TH. 2016. The business of bodies: Ethical perspectives on for-profit body donation companies. Clin Anat 29: 25-29. doi: $10.1002 /$ ca.22643

da Rocha AO, Tormes DA, Lehmann N, Schwab RS, Canto RT. 2013. The body donation program at the Federal University of Health Sciences of Porto Alegre: a successful experience in Brazil. Anat Sci Educ 6: 199-204. doi:10.1002/ase.1335

Gangata H, Ntaba P, Akol P, Louw G. 2010. The reliance on unclaimed cadavers for anatomical teaching by medical schools in Africa. Anat Sci Educ 3:174-183. doi:10.1002/ase.157

Gürses IA, Coşkun O, Öztürk A. 2018. Current status of cadaver sources in Turkey and a wake-up call for Turkish anatomists. Anat Sci Educ 11:155-165. doi:10.1002/ase.1713

Habicht JL, Kiessling C, Winkelmann A. 2018. Bodies for anatomy education in medical schools: an overview of the sources of cadavers worldwide. Acad Med, published ahead of print, March 20, 2018. doi: 10.1097/ACM.0000000000002227

Hallam E. 2017. Relational anatomy - Dissecting and memorialising the dead in medical education. Medicine Anthropology Theory 4:99124. doi:10.17157/mat.4.4.314

Halou H, Chalkias A, Mystrioti D, lacovidou N, Vasileiou PV, Xanthos T. 2013. Evaluation of the willingness for cadaveric donation in Greece: a population-based study. Anat Sci Educ 6:48-55. doi:10.1002/ase.1304

IFAA (International Federation of Associations of Anatomists). 2012. Recommendations of good practice for the donation and study of human bodies and tissues for anatomical examination. In: Plexus - Newsletter of the IFAA. p 4-5. http://www.ifaa.net/wp- content/uploads/2017/ 09/plexus_jan_2012-screen.pdf (accessed March 18, 2018).

Jones DG, Whitaker MI. 2012. Anatomy's use of unclaimed bodies: reasons against continued dependence on an ethically dubious practice. Clin Anat 25:246-254. doi:10.1002/ca.21223

Saha A, Sarkar A, Mandal S. 2015. Body donation after death: the mental setup of educated people. J Clin Diagn Res 9:AC05AC09. doi:10.7860/JCDR/2015/12246.6011

Shiffman J, Levinson R. 2018. Made in America: U.S. body brokers supply world with human torsos, limbs and heads. Part 9 of "The body trade" - A Reuters series. Feb 8, 2018. https://www.reuters.com/investigates/specialreport/usa-bodies-export (accessed March 18, 2018).

Simao TRP, Miglino MA, da Silva JB, McManus C, Liberti EA. 2016. Implementation of a program of voluntary body donation for anatomical study in the University of Sao Paulo, Brazil. Int J Morphol 34:1494-1501.

Winkelmann A, Güldner FH. 2004. Cadavers as teachers: the dissecting room experience in Thailand. BMJ 329:1455-1457. doi:10.1136/ bmj.329.7480.1455 